\title{
03(XIV)-76 骨折整復支援ロボティックシステムにおける画像ナビゲーション
}

○中島義和 ${ }^{a, d}$, 古結義浩 ${ }^{e}$, 田代孝仁 ${ }^{d, a}$, 岡田俊之 ${ }^{d, a}$, 佐藤嘉伸 ${ }^{a, d}$, 鮫島誠 ${ }^{e}$, 菅野伸彦 ${ }^{b}$, 斉藤正伸 ${ }^{f}$, 米延策雄 ${ }^{\mathrm{f}}$, 光石衛 ${ }^{\mathrm{g}}$, 佐久間一郎 ${ }^{n}$, 吉川秀樹 ${ }^{b}$, 越智隆弘 ${ }^{\mathrm{i}, \mathrm{c}}$, 田村進一 ${ }^{\mathrm{d}, \mathrm{a}}$ 大阪大学大学院 $\left\{\right.$ 医学系研究科 $\left\{{ }^{\mathrm{a}}\right.$ 多元的画像解析分野, 㗊官制御外科学, ${ }^{\mathrm{c}}$ ロボテイツクス治療学 $\}$, ${ }^{\mathrm{d}}$ 情報科学研究科\}, e三菱重工業株式会社, f国立大阪南病院, 東京大学大学院 $\left\{{ }^{\mathrm{g}}\right.$ 工学采研究科, ${ }^{\mathrm{i}}$ 新領或創成科学研究科\}, i国立相模原病院 Image-based Navigation in a Robotic System for Bone Fracture Reduction

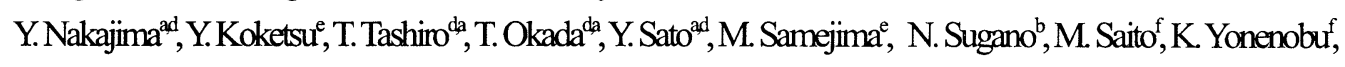
M. Mitsuishi ${ }^{\text {, }}$, L Sakuma ${ }^{\text {h }}$,H. Yoshikawa, T. Ochic, S. Tamura ${ }^{\text {ad }}$

$\left\{\left\{{ }^{a}\right.\right.$ Div. of Interdisciplinary Image Analysis, ${ }^{b}$ Dept. of Onthopaedic Siryery, ${ }^{c}$ Div. of Robotic Therapy $\}$, Gractuate School of Medicine, ${ }^{d}$ Gractuate School of Information Science and Technology\}, Osaka University, $\quad{ }^{e}$ Missubishi Heany Industries, Ltd, $\quad{ }^{f}$ Osaka Minami National Hospital, $\left\{{ }^{g}\right.$ GractuateSchool of Engineering, ${ }^{h}$ Grachuate School of Frontier Sciences\}, the Universityof Tokyo, $\quad{ }^{i}$ National Sagamihara Haspital

\begin{abstract}
We have developed a robotic system for the reduction of bone fracture. In this paper, we describe an image-based navigation system as a component of the robotic system. Voxel-based 2-D/3-D registration and volume registration techniques are employed for the detection of bone fragment positions and the determination of reposition path, respectively. All coordinate systems are integrated in the navigation and then robot is controlled. The results of accuracy validation by using computer simulation are shown.
\end{abstract}

Keywords: computer aided surgery, bone fracture reduction, 2-D/3-D registration, volume registration

\section{1. はじめに}

高龄化社会の進展に伴，大腿骨頸部骨折の症例は年々堌加し ている.この骨折の治療は, 牽引, 回旋等こよる整復, 固定の3つ の手順で行われる. 牽引およひ整復は多大な労力を要し, また, 整復状態確認のために, 複数回のX線透視撮影を伴う. 我々は, (1)ロボッ小による術者の被曝可辟, 毫引·整復の労力低減, (2)3次 元画像計測技術こよる患者の被瀑量の低減老目的しし, 骨折整復 を支援するロボテイックシステムを開発した. 本稿では, 計測·制 御定行う画像ナビゲーションの観点からシステムについて述べる. 骨折整復支援は対象となる症例数の規模力ら社会的意義が大きく, 我々以外にも複数の組織で, ナビゲーションシステムあるいは口 ボットによる骨折整復支援ンステムの研究が行われている1), 2).

\section{2. システム構成}

システムの外観を Fig1 に示す. システムは, 光学式3次元位置 計測装置, X線透視撮影装置, ナビゲーション用コンピュータ, カ 一ボンベッド, およびロボットから構成される. 光学式3次元位置 計測装置は，Fg.2およびFig.1の知(白)に示す大煺骨遠位骨片， X線透視撮影装置, およびロボットに取付けられたマーカの位置 計測を行う. X線透視撮影装置は, 近位骨片の位置姿勢, および 遠位骨片とその位置計測マーカの相刘位置姿勢を計測するため に用いる. ナビゲーションシステムは, 光学式了次元位置計測装置 およびX線透視装置で計測されたデータを統合し, 遠位骨片の動 作パス(骨折整復パス)を計算し，ロボットを制御する.ロボットは, 足首で脚定把持, 整復動作克行う。

\section{3. 動作プロトコル}

ナビゲーションシステムは, 各システム要素で計浿た座標系 間相刘位置姿勢を統合して骨折整復パスを計算し，ロボッ小を制御 する. ナビゲーションシステムが統合する座標系をFig3に示す.

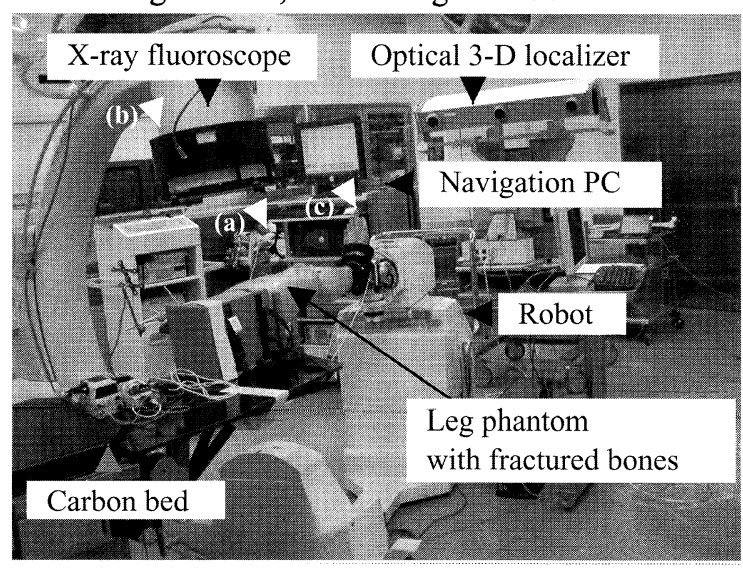

Fig.1 Appearance of the system
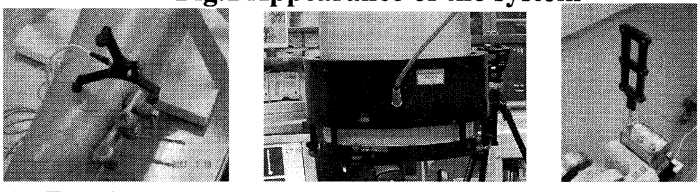

(a) For distal bone (b) For fluoroscope (c) For robot

Fig.2 Markers for localization

Fig.3(b)に示すように, ナビゲーションシステムでロボットを制卸 するためには, 各位置計測マ一カの位置姿勢のほか, 口ボット位 置姿勢 $T_{\text {rboor }}$, 鼓位骨片位置姿勢 $T_{\text {distal }}$, 近位骨片レジストレーショ

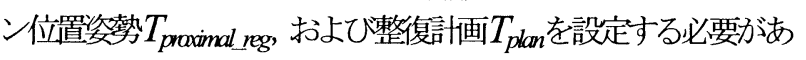
る.

\section{1. 整復計画}

骨折整復状態の計画は, 術前に, CT 画像を利用して行う. まず, CT 画像冺それぞれの骨片の分割画像を生成与る. 反刘僋脚画 像の鏡像に対して, 各々の骨片分割画像のボリュームレジストレ ーションを行い, 2つの骨片の相対位置姿勢を計算し, 整復計画 
$T_{\text {plan }}$ とする. 整復計画は, 術中においては静的なデータとして使 用寸る.

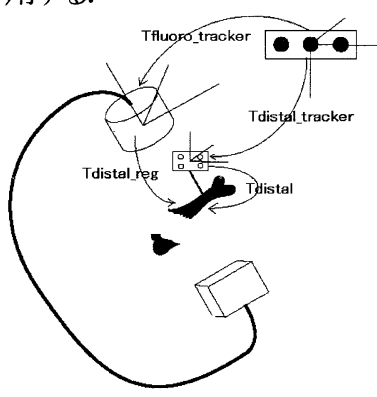

(a) Registration of distal bone

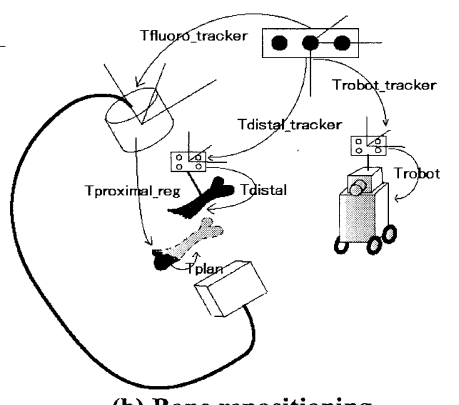

(b) Bone repositioning

Fig.3 Coordinate systems in the navigation

\section{2. ロボット座標系キャリブレーション}

ロボット座墂系キャリブレーションは, ロボットアーム先端こ取り 付けたマーカの3次元位置姿勢計珼ながらの各軸周りのロボ ットアーム回転運動で行う. また, 各軸力向へのロボットアーム並 進運動計測による回転軸驴並進軸の整合性確認および回而, 並 進の双方における軸直交性と移動量の確涩老行う。

\section{3. 骨片位置計測}

骨片の位置計測には，ボクセル値こ基づく 2-D/3-D レジストレ ーションを用いだ゙. まず, 術前に生成した骨片領域の分割画像 (3. 1節)を用意する. 術中では, 位置計測のためX線透視撮影装 置による複数力向撮影(Fig4)を行い, 2-D/3-D レジストレーション によって, 分割画像と撮影画像力整合するように各分割画像の3次 元位置を更新する.レジストレーション結果の例在 Fig5 に示す. Fig.5 は, 解りやすさのため, 撮影X線画像上に, 分割画像加生 成した骨片の表面形犾モデルを重畳表示している。骨片位置計測 は, 遠位骨片レジストレーション位置姿勢 $T_{\text {disal_rgg }}$ の獲得(Fig3(a)), および近位骨片レジストレーション位置姿勢 $T_{p \text { proxmal } r g g}$ の獲得 (Fig3(b))に使用される. また, 遠位骨片位置姿勢 $T_{\text {dival }}$ は, 遠位骨 片レジストレーション位置管势 $T_{\text {disal_reg }}$ より,

$$
T_{\text {distal }}=T_{\text {distal_tracker }}^{-1} \cdot T_{\text {fluoro_tracker }} \cdot T_{\text {distal_reg }}
$$
で求められる。

\section{4. 整復位置姿勢計算}

術中では, Fig3(b)に示寸ように, 骨片位置計測(3.3節)により 得られた近位骨片の位置姿勢力ら, 整復計画(3.1節)に基づい て遠位骨片の目標位置姿勢を求め, そこからロボットの移動量を 計算する. 遠位骨片の目標位置および現在位置から求められる口 ボッ移動量よ,

$$
\begin{aligned}
& T_{\text {robot_motion }}=T_{\text {robot }}^{-1} \cdot T_{\text {robot_tracker }}^{-1} \cdot T_{\text {fluoro_tracker }} \cdot \\
& \quad T_{\text {proximal_reg }} \cdot T_{\text {plan }} \cdot T_{\text {distal }}^{-1} \cdot T_{\text {distal_tracker }}^{-1} \cdot T_{\text {robot_tracker }} \cdot T_{\text {robot }}
\end{aligned}
$$

で求められる. 整復パスは, 移動点間の線形補間, 女る いは双四元数による補間で生成する.

\section{4. 動作精度推定}

コンピュータシミュレーションによる䛊差解析をを行い, システ ムの動件精度を推定した. 各システム要素こおける推定RMS 誤
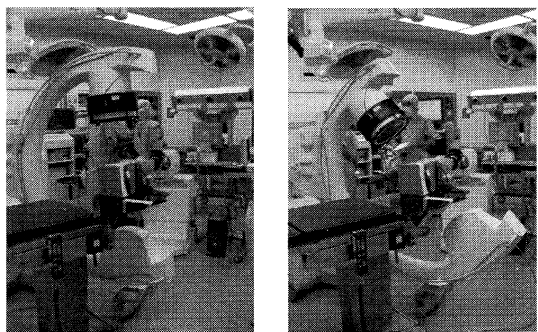

Fig.4 Stereo fluoroscopy

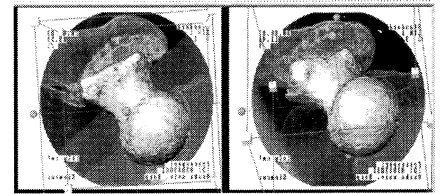

Fig.5 Result of 2-D/3-D registration

差を以下に示寸. 整復計画 $T_{p k n}$ の誤差は $4.01 \mathrm{~mm}, 2.48 \mathrm{deg}$, ロボ ッ小座標采キヤリブレーション $T_{\text {robot }}$ の誤差は $0.08 \mathrm{~mm}, 0.04 \mathrm{deg}$, 骨 片位置計測における誤差は, 遠位骨片 $T_{\text {disal }}$ rg $2.65 \mathrm{deg}$, 近位骨片 $T_{\text {proximal } r e g}$ は $1.57 \mathrm{~mm}, 2.54 \mathrm{deg}$ であった. また, 各要素における誤差を統合したシステム䛊差を示寸. 3次元位置 計測こよるシステム誤差は $1.11 \mathrm{~mm}, 0.20 \mathrm{deg}$, システム全体の誤差 すなわちナビゲーションシステムがロボットに与える指令值の誤 差は, 4.74mm, 4.45degであった. 整复婳俩誤差推定では, 左右 骨の非称性に起因寸る偏誤差を含む. 偏誤差を考慮しない 場合の計画融差(ばらつき誤差は $0.22 \mathrm{~mm}, 0.70 \mathrm{deg}$, システム全 体の誤差よ2.60mm, 3.63deg であった.

\section{5. まとめ}

術者の被暴回辟 牽引·整復の労力低减, 患者の被暴量の低减 を目的として, 骨折整復を支援するロボティックシステムを開発し た. コンピュータシミュレーションによる誤差推定を行い, 動作精 度を確涊した. 本システムは術前 CT 画像を用いる. 今後, 術前 CT 画像撮影老不要こするため, 術 Iso-C 3D 画像(術中 CT 画 像) 術中透視最影画像のみからの整復位置姿勢匴手法老確 立したい. また, 各要素の洗練こよるシステムの高精度化を行い， 臨宋啇用老目指寸。

詩辞 本研究の一部丈, 日本学術振瞘会未来開拓推隹事業「外科 領域を中心とするロボティックシステムの開発」 (JSPS-RFTF99100903), 日本学術振興会科研費補助金(若手研究 (B)14780281)より援助を受怰ている.

文献

1) L Joskowicz, et al: FRACAS: a system for computer-aided image-guided long bone fracture surgery, Journal of Computer-Aided Surgery, 3(6), 271-288 (1999).

2) R. Westphal, et al: Fracture reduction using a telemanipulator with haptical feedback, Computer Assisted Radiology and Surgery, International Congress Series 1256, 1369 (2003).

3) J. Weese, et al::Voxel-Based 2-D/3-D Registration of Fluoroscopy Images and CT Scans for Image-Guided Surgery, IEEE Trans. on Information Technologyin Biomedicine, 1(4), 284293(1997).

4) 櫻木太, 他: 異種3次元データ統合システムの構造記述と誤差解析 のためのシステムシミュレータ,電子情報通信学会論文誌 $(D-I I)$, J86-D-II(1),(2004)(inpress). 


\section{3(XIV)-77 反対側を利用した大腿骨骨折整復計画とその精度検証}

○岡田 俊之 ${ }^{a, b}$ 渡邊 曜子 $a, b$ 中島 義和 $b, a$ 佐藤 嘉伸 $b, a$ 小山 毅 $c$ 菅野 伸彦 $c$ 米延 策雄 $e$ 吉川 秀樹 ${ }^{c}$ 越智 隆弘 $d, f$ 田村 進一 $b, a$

${ }^{a}$ 大阪大学大学院情報科学研究科 コンピュータサイエンス専攻 大阪大学大学院医学系研究科 $\left\{{ }^{b}\right.$ 多元的画像解析分野, ${ }^{c}$ 器官制御外科学講座, ${ }^{d}$ ロボテイックス治療学分野 $\}$ ${ }^{e}$ 国立大阪南病院, ${ }^{f}$ 国立相模原病院

Preoperative planning of Femur Fracture Reduction Using Contralateral Bone Image and Its Accuracy Validation

Toshiyuki Okada $^{a, b}$, Yoko Watanabe ${ }^{a, b}$, Yoshikazu Nakajima ${ }^{b, a}$, Yoshinobu Sato $^{b, a}$, Tsuyoshi Koyama $^{c}$, Nobuhiko Sugano $^{c}$, Kazuo Yonenobu ${ }^{e}$, Hideki Yoshikawa ${ }^{c}$, Takahiro Ochi ${ }^{d, f}$, and Shinichi Tamura ${ }^{b, a}$

${ }^{a}$ Dept. of Computer Science, Osaka University Graduate School of Information Science and Technology $\left\{{ }^{b}\right.$ Div. of Interdisciplinary Image Analysis, ${ }^{c}$ Dept. of Orthopaedic Surgery, ${ }^{d}$ Div. of Robotic Therapy $\}$, Osaka University Graduate School of Medicine ${ }^{e}$ Osaka Minami National Hospital, ${ }^{f}$ National Sagamihara Hospital

Abstract: The number of cases of femur fracture is increasing with progress of an aging society year by year. The research of the robotic system and navigation system is widely done in orthopedics. In these computer aided systems, it is the one of the important subjects how to reduce fracture accurately. In this study, we focused attention on the body symmetry, applied fracture reduction planning using contralateral bone, and validated its accuracy. In fracture reduction planning, we register between the mirror image of the contralateral bone and the proximal or distal fragments using the preoperative CT image, and calculate the relative positions and orientations. We validated the accuracy of this fracture reduction planning by using the CT image of the healthy bone. Using relative position and orientation of the healthy bone as the ground truth, accurate validation is available. In the experiments, bias of translation and rotation were $4.0 \mathrm{~mm}$ and 2.3 degrees and precision of those were $0.23 \mathrm{~mm}$ and 0.71 degrees.

Keywords: fracture reduction, preoperative planning, contralateral bone, volume registration

\section{1 はじめに}

高齢化社会の進展に伴い, 大腿骨骨折の症例は年々増 加している.このため, 整形外科領域ではロボティック システムやナビゲーションシステムの研究が盛んに行 われている [1].これらのシステムは, 術中における医 師の労力を削減するだけでなく，患者のX線被曝量を 軽減できる可能性がある。しかしその一方で，これらの 支援システムにおいて，どのようにして正確な骨折の整 復を行うかが重要な課題となっている $[2]$. 整復位置を 求める方法の一つとして, 術前の CT 画像加正確に骨 折面を抽出し，それらの面同士を合わせることが考えら れる。しかし，CT画像から骨折面を正確に抽出するこ とは難しく, 複雑骨折への適用を考慮すると安全性が問 題となる。そこで我々は, 人体の形状の左右対称性に着 目し，反対側の画像情報を用いた剛体ボリュームレジス トレーションによる整復計画法を試みる。この整復計 画法の精度については, 正常骨に対して仮想的に整復計 画法を適用する手法を提案し, 検証を行う.

\section{2 整復計画法}

整復計画は術前のCT 画像を用いて行う。まず, 近位 部，遠位部の 2 つの骨片に対して，骨折面を含まないよ うに関心領域を設定する。これは，骨折面の複雑な形状 が関心領域に含まれることによる，レジストレーション への悪影響を避けるためである. 次に, 反対側画像の鏡 像と近位部，遠位部の骨片それぞれとのレジストレー ションを行う。レジストレーションの初期位置は近位 部, 遠位部に対してそれぞれ目視により最適な位置を指 定し，レジストレーションの評価尺度には相関係数を用 いる. 以上のようにして得られた近位部, 遠位部の位置 姿勢 $T_{P}, T_{D}$ より, 近位部に対する遠位部の相対位置姿 勢 $T$ を求める (Fig. 1).

$$
T=T_{D}^{-1} \cdot T_{P}
$$

この $T$ を骨折の整復計画とする.

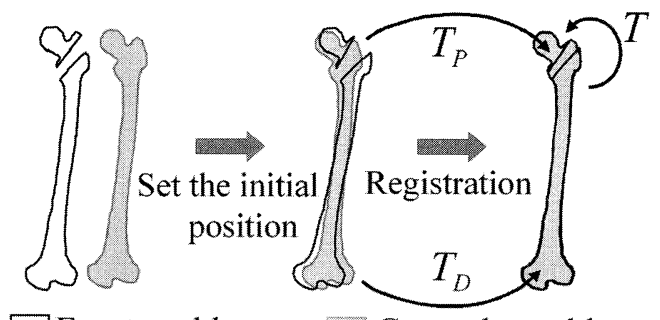

Fractured bone

Contralateral bone

Fig. 1: Fracture reduction method

\section{3 精度検証法}

精度検証は, 骨折していない大腿骨 CT 画像に対して 片側に骨折面を仮想的に設定し，これに整復計画を適 用することにより行う．精度検証の手法を以下に示す。 まず, Fig. 2に示すように正常骨のCT画像に骨折面を 設定し, 近位部, 遠位部に相当する関心領域を決定する。 次に, 反対側の鏡像とそれらの領域内の骨片それぞれの レジストレーションを行う。その際の初期位置は次の ようにして決定する。まず,反対側の鏡像とそれらの領 域内の骨片それぞれを高精度にレジストレーションを 行って,できる限り反対側とそれらの骨片の位置を合わ せておく。この最適な収束位置から平行移動および回 転を表す 6 パラメー夕 $\left(x, y, z, \theta_{x}, \theta_{y}, \theta_{z}\right)$ それぞれに対 して, ガウス乱数による誤差を与えたものを初期位置と する [3]. レジストレーションの結果得られた 2 つの骨 片の相対位置姿勢 $T_{\text {est }}$ と正解值との距離誤差, 回転誤 差を評価する。ここで, 仮想的な骨折によって得られる 近位部, 遠位部の 2 つ骨片は，その相対位置姿勢が既 知であるため，この位置姿勢を骨折整復の正解值 $T_{t r u e}$ とする。これを用いることにより,整復計画によって得 られた位置姿勢の精度を正確に検証することができる。 


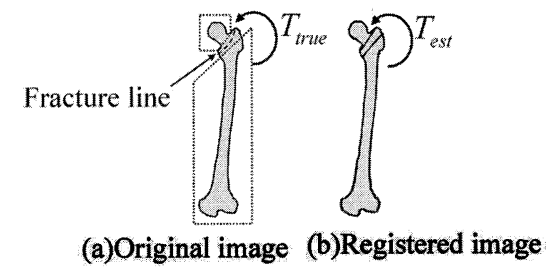

Fig. 2: Accuracy validation method

\section{4 実験結果と考察}

実験には正常骨の CT 画像と軽度の大腿骨頭壊死症 患者の CT 画像をそれぞれ1例ずつ用いた。前者は視 覚的にほほ左右対称であったが (Fig. 3)，後者は骨頭 部の大きさがやや異なっていた. 正常骨の CT 画像は 画像サイズが $512 \times 512$ pixel, Field Of View (FOV)が $450 \times 450 \mathrm{~mm}$, 骨頭部と膝部のスライス厚, スライス間 隔はともに $2 \mathrm{~mm}$, 骨幹部のスライス厚, スライス間隔 はともに $10 \mathrm{~mm}$ であった。壊死症患者の CT 画像は画 像サイズが $512 \times 512$ pixel, FOVが $420 \times 420 \mathrm{~mm}$, スラ イス厚, スライス間隔はともに $3 \mathrm{~mm}$ であった.レジス トレーションの初期位置は目視によりマニュアルで正 確にレジストレーションを行って得た位置より, $3 \mathrm{~mm}$, 3 度の範囲で誤差を与えたものとし，これを各骨片につ き, 20 回ずつ行った. 遠位部のレジストレーションに関 しては, 膝の部分を関心領域に含めた場合と含めない場 合の 2 通りについて実験を行った.

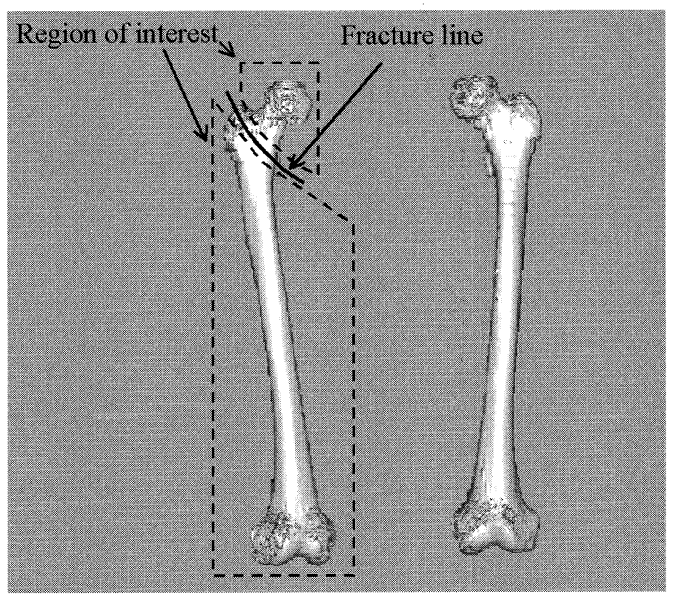

Fig. 3: Left and right femur models reconstructed from CT data of healthy volunteer. The fracture line and regions of interests specified in the experiment are shown on these models

実験の結果, Table 1に示すように, 正常骨の相対位 置姿勢の誤差は膝の部分を含めた場合の方が膝の部分 を含めない場合と比べて偏り誤差，ばらつき誤差とも に小さくなった。壊死症患者の骨の相対位置姿勢の誤 差は膝の部分を含めた場合の方が膝の部分を含めない 場合と比べて偏り誤差, ばらつき誤差ともに大きくなっ た．相対位置姿勢の誤差は正常骨の方が壊死症患者の 骨と比べて, 膝の部分を含めた場合, 含めない場合とも
に偏り誤差, ばらつき誤差は小さくなった.

正常骨の相対位置姿勢の誤差が, 膝を含めた場合の 方が膝を含めない場合より小さくなったのは膝の情報 が有効に働いたためであると思われる。また，今回用い た壊死症患者では, 骨の相対位置姿勢の誤差は, 膝を含 めない場合の方が膝を含めた場合より小さくなってい たが, 実験に用いたデー夕数が1つであったため, 壊死 症患者の一般的な結果ということはできない。文のた め, 今後デー夕数を増やして実験を行い, 一般性を調べ る必要がある. 相対位置姿勢の偏り誤差がやや大きかっ たのは，近位部と反体側とのレジストレーションにおい て誤差が大きくなったことが考えられる。相対位置姿 勢の誤差は正常骨の方が壊死症患者の骨と比べて小さ くなっていたことから, 今回用いた正常骨のデータに関 しては, 骨折整復計画を目的とした場合, その精度は許 容範囲内であると考えられる。

Table 1: Translation error and rotation error of relative position and orientation

(a) Healthy bone (b) Diseased bone

\begin{tabular}{|c|c|c|c|c|c|}
\hline \multicolumn{2}{|c|}{} & \multicolumn{2}{c|}{ translation [mm] } & \multicolumn{2}{c|}{ rotation [deg] } \\
\cline { 3 - 6 } \multicolumn{2}{|c|}{} & bias & precision & bias & precision \\
\hline \multirow{2}{*}{ (a) } & with knee & 4.0 & 0.23 & 2.4 & 0.71 \\
\cline { 2 - 6 } & without knee & 5.0 & 0.52 & 2.8 & 0.84 \\
\hline (b) & with knee & 5.4 & 0.89 & 4.5 & 2.0 \\
\cline { 2 - 6 } & without knee & 4.5 & 0.84 & 4.3 & 2.0 \\
\hline
\end{tabular}

\section{5 まとめ}

本稿では，反対側を利用した剛体ボリュームレジス トレーションによって整復計画を行った. そして, 仮想 的に骨折面を設定した正常骨に対して，この整復計画 を行うことにより，完全な正解值による精度の検証を 行った. 実験の結果, 正常骨の各骨片の相対位置姿勢の 距離誤差, 回転誤差は膝を含めた場合, それぞれ偏り誤 差が $4.0 \mathrm{~mm}, 2.3$ 度，ばらつき誤差が $0.23 \mathrm{~mm}, 0.71$ 度 であった. 今回は精度検証に用いたデー夕数は 2 であっ たが, 今後, 適用デー夕数を増やし，反対側を利用した 骨折整復計画の妥当性と精度限界を検証する。

謝辞: 本研究の一部は, 日本学術振興会未来開拓推進 事業「外科領域を中心とするロボテイックシステムの開 発」(JSPS-RFTF99I00903)，「文部科学省科学研究費 補助金」(特定領域 (2)15070207)，「日本学術振興会科 研費補助金」(若手研究 (B)14780281) より援助を受け ている。

\section{参考文献}

[1] Joskowicz L, Milgrom C, Simkin A, Tockus L, Yaniv Z, "FRACAS: a system for computer-aided image-guided long bone fracture surgery", Computer Aided Surgery, pp.271-88, March. 1998.

[2] Hofstetter R, Slomczykowski M, Krettek C, Koppen G, Sati M, Nolte LP, "Computer-assisted fluoroscopy-based reduction of femoral fractures and antetorsion correction", Computer Aided Surgery, pp.311-25, May. 2000.

[3] 渡邊 曜子, 桝本 潤, 笹間 俊彦, 佐藤 嘉伸, 菅野 伸彦, 西井孝, 三木 秀宣, 吉川 秀樹, 越智 隆弘, 田村進一, ”人工股関節全置換術における術前, 術 後 CT 画像間の剛体レジストレーション”, JAMIT Frontier 2003, pp.19-24, January. 2003. 


\title{
03(XIV)-78 複数X 線像とCT 間のレジストレーションを用いた 前十字靶帯再建術のためのナビゲーションシステム
}

\author{
${ }^{1} \bigcirc$ 空閑 護, ${ }^{2}$ 安田 和則, ${ }^{1}$ 波多 伸彦, ${ }^{1}$ 土肥 健純 \\ 1東京大学大学院情報理工学系研究科 \\ 2 北海道大学大学院医学研究科外科治療学
A Navigation System for ACL Reconstruction Using Registration between Multi-Plane Fluoroscopic Images and CT Images \\ ${ }^{1}$ M. Kuga, ${ }^{2}$ Y. Yasuda, N. Hata, and ${ }^{1}$ T. Dohi \\ ${ }^{1}$ Graduate School of Information Science, The Univ of Tokyo \\ 2 Dept of Medical Bioengineering and Sports Medicine, Hokkaido Univ
}

\begin{abstract}
A high-precision navigation system for Anterior Cruciate Ligament(ACL) reconstruction is presented. In the system, 3D CT data is used to visualize the structure of bones and optical localizer is used to detect the position of femur, tibia and surgical tools. Since CT images are acquired preoperatively and markers are fixed to bones intraoperatively, their relative position has to be initialized. To achieve this initialization, 2D/3D registration method between $\mathrm{CT}$ model and X-ray images was developed. The registration is performed by minimizing the difference between contour lines. As ACL reconstruction requires precision, three X-ray images taken from different angles are used for the registration. Simulated registration shows the mean error to be less than $1.5 \mathrm{~mm}$.
\end{abstract}

Key words: image-guided surgery, navigation, 2D/3D registration, X-ray fluoroscopy, CT

\section{1.はじめに}

前十字勒帯の再建術では,勒帯挿入穴の位置決め を高い精度で行うことが求められ,そこでの誤差が 回復後の患者の運動能力に影響する ${ }^{11}$.

術中に骨と術具の位置関係を可視化する方法とし てはX 線写真が利用できるが,これは「2 次元の表示 のみ」,「被爆の問題から撮影できる枚数に制限があ る」といった問題点がある.そこで,術中にガイド,脛 骨,大腿骨の3 次元の位置関係をリアルタイムに表示 するナビゲーションシステムの開発を目的とする.

\section{2. ナビゲーションシステムの概要と課題}

ナビゲーションの表示で使用する脛骨と大腿骨の 3D モデルは術前の CT 画像から作成し, ガイド, 脛骨, 大腿骨の位置関係の計測には光学式の位置計測セン サ (POLARIS，NDI) を使用する.このマーカを骨に取 り付けるのは術中であるため, これらの位置関係を 術中の X線像とCT モデルとのレジストレーションに よって初期化する.マーカはFig. 1 (a) に示すように 樹脂と金属を使って作成し, X線写真にはレジストレ ーションに適した形状で写るようにする (Fig. 1 (b) ) . (a)

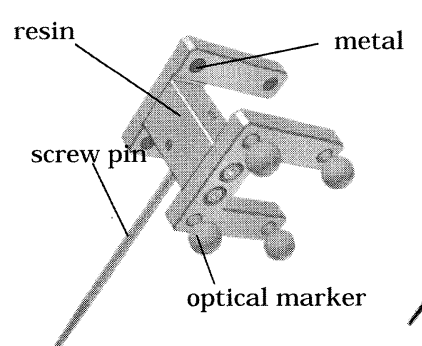

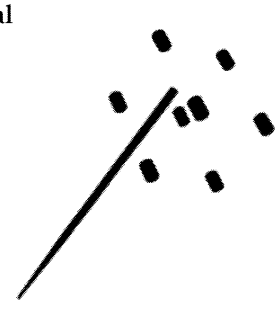

(b)
Fig. 1. (a) Marker for registration and tracking (b) Marker in X-ray image

X 線写真には輪郭線が強く現れる特徵があるため, レジストレーションは X 線写真と $3 \mathrm{D}$ モデルの輪郭 線間の距離を小さくすることによって行う. ${ }^{2)} こ の$ 際, 輪郭線が複雑な形状をしていればモデルの正確な位 置·姿勢を求めることができる. しかし, 大腿骨や脛 骨のような単純な形状のモデルは 1 枚の X 線写真だ けを使ったレジストレーションでは, Fig. 2 の Z, Roll, Pitch 方向の誤差が大きくなってしまう. ${ }^{31}$ そこで, $X$ 線写真を正面, 側面, 上面から撮影し, この 3 枚からの情報を用いたレジストレーション法を提 
案する。

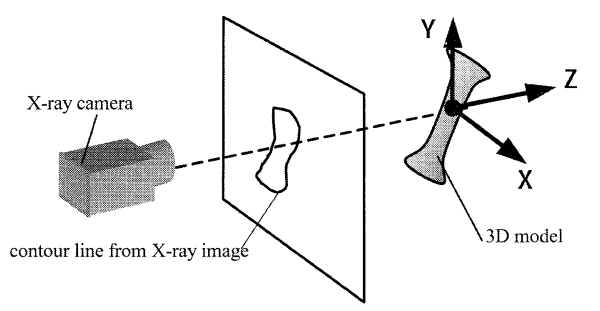

Fig. 2. Definition of axes for registration

3. 複数 X 線像による高精度レジストレーション 正面, 側面, 上面と正確に 90 度ずつ回転させた X 線写真を撮影寸るのが理想であるが,実際には X 線 撮像装置と他の装置との干渉の問題から術中にこれ を行うのは難い.また,撮像装置の位置を計測しレジ ストレーションに使用する方法も考えられるが, 誤 差が大きい.従って,撮像装置の大まかな位置以外は 未知として,レジストレーションを行う必要がある. そこで,X線写真中に写ったマーカを用いてそれぞれ の写真間の位置関係を定める.具体的には,以下の手 順で行う。

1.正面の写真を使って骨とマーカのレジス トレーションを行う(Fig.3(a)).

2.側面の写真でマーカのレジストレーションを行 い,1. で求めた相対位置に骨を配置する (Fig.3(b)).

3.正面写真では誤差が大きいが,側面写真では誤差 を小さくできる方向(正面写真から見た Z,Roll 方 向)のみに骨を動かし,最適位置を求める (Fig.3(c)).

4.上記 2.,3. と同様の手順を上面の写真についても 行う(Fig.3(d)).

4. レジストレーション評価実験及び結果

$3 \mathrm{D}$ モデルから作成した 3 枚の画像を用いてレ ジストレーションの評価実験を行った.結果は平 均誤差が $1.5 \mathrm{~mm}$ で計算時間は,Pentium4 $2.8 \mathrm{GHz}$ のPC を使用し,画像サイズを 256x256 として約 3 分間であった.収束の様子を Fig.4 に示す.

\section{5.まとめ}

靶帯再建術のための高精度のナビゲーションを実 現するため,複数 X 線像を用いたレジストレーショ ン法を提案し, 実験を通してその有効性を確認した。 勒帯再建術には $1 \mathrm{~mm}$ 以下の誤差が必要であるため,
今後は使用する解像度を上げるなどして高精度化を 目指す。
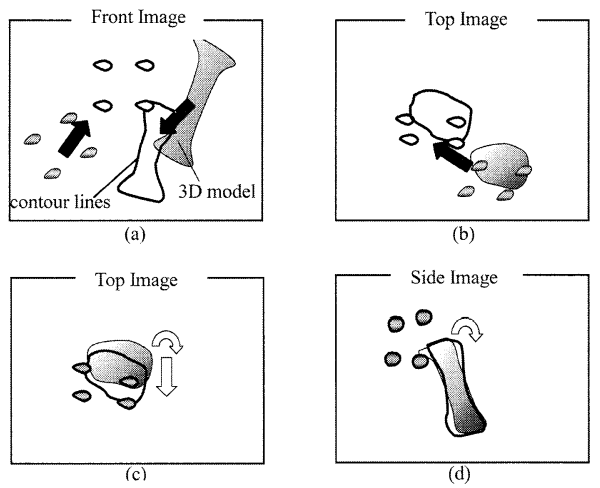

Fig. 3. Multi-plane registration method (a)marker and bone are registered in front image (b) registration is performed with marker and bone is fixed to the marker(c) bone is registered along $\mathrm{Z}$ and pitch axis in front coordinates (d)last registration in top image
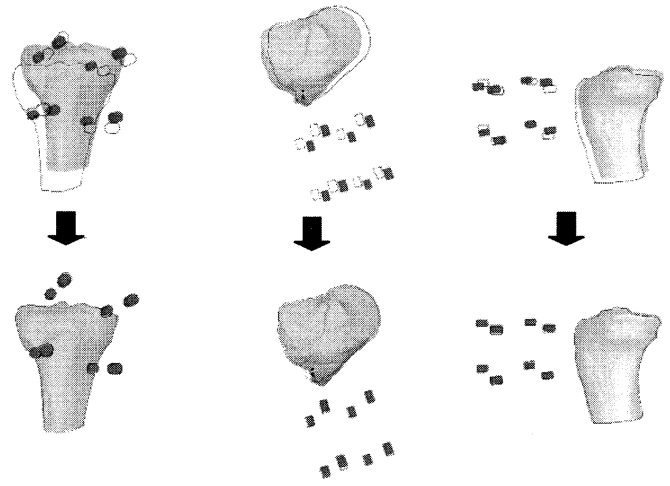

Fig. 4. Evaluation of registration method. Images above show contour lines and 3D models before registration and images below show those after registration.

参考文献

1) Yasuda K., et al : Effects of initial graft tension on clinical outcome after anterior cruciate ligament reconstruction Autogenous doubled hamstring tendons connected in series with polyester tapes: AMERICAN JOURNAL OF SPORTS MEDICINE, 1997.

2) Alan Liu, et al : $3 \mathrm{D} / 2 \mathrm{D}$ registration via skeletal near projective invariance in tubular objects, MICCAI98, pp952-963(1998)

3) 喜多 泰代; Dale L. Wilson; J.Alison Noble 他 : 汎用 3 D-2D レジストレーション手法とその応用例,情報処理学会 研究報告. 2000(7) pp73-8 

支援の検討

$\bigcirc$ 菅野伸彦 ${ }^{1)}$, 西井孝 ${ }^{1)}$, 三木秀宣 ${ }^{1)}$, 小山毅 ${ }^{2)}$, 高尾正樹 ${ }^{1)}$, 吉川秀樹 ${ }^{1)}$, 越智隆弘 ${ }^{2)}$

1) 大阪大学大学院医学系研究科 器官制御外科学, 2) ロボティクス治療学

Robot-assisted acetabular reaming for cup placement in total hip arthroplasty Nobuhiko Sugano*, Takashi Nishii*, Hidenobu Miki*,Tsuyoshi Koyama**, Masaki Takao*, Hideki Yoshikawa*, Takahiro Ochi**

Department of Orthopaedic Surgery, Osaka Univ. Graduate School of Medicine* Department of Medical Robotics and Image Sciences, Osaka Univ. Graduate School of Medicine**

【Abstract】 Force transferred to bone phantom materials during hemispherical reaming by an experienced joint surgeon and speed of the reamer advancement were measured to develop a robot-assisted acetabular reaming system for total hip arthroplasty. The surgeon seemed to keep the force constant around $100 \mathrm{~N}$ during reaming. Based on the data of reaming with a hand-held tool by the surgeon, robot-assisted force-feedback reaming was performed under the condition that the maximum force was set to be $100 \mathrm{~N}$. This robotic reaming was accurate and quick enough to be used clinically. However, optical tracking of the reamer was necessary to correct an error of reaming in the direction of reamer advancement due to the elasticity of the rigid frame of work.

【Key words】 Total Hip Arthroplasty, Robot-Assisted Acetabular Reaming, Navigation

\section{【はじめに】}

ナビゲーションにより、人工股関節全置換術 $(\mathrm{THA})$

におけるリーミングやカップの位置を3次元的に正 確に把握できる現在、今後期待されることは、手で 保持した術具でのリーミング時に起こりうる術具回 転反力によるリーミング位置ずれやカップを臼蓋に 打ち込む際の位置ずれを補正できるロボット支援シ ステムである。今回、THAにおける臼蓋リーミングの ロボット手術支援について基礎的な評価試験を行っ たので報告する。

【材料と方法】

手で保持した術具での臼蓋リーミング時に臼蓋に 作用する掘削負荷を再現評価し、その結果をロボッ トリーミングに適用するため、掘削負荷検出用の力 センサーを介して SawBone 人工骨材を取り付けた掘 削負荷測定装置（写真 1 : 製作／測定協力 大阪機 工(株) を作製した。リーマーは Precimed 社製で、 Sawbone 材料、カセンサー、測定環境を表 1 に示す。 各実験材料に対し、通常の手術と同様の力加減で関 節外科医が半球状に材料をリーミングした。

掘削試験は、新品と使用済みの 2 種類の半球リー マー（新、旧と呼ぶ）を使用し、人工骨材は密度の 異なる 4 種類の材料（\#9,10,11, 12 と呼ぶ）をそれ ぞれ 3 回ずつ実施し、測定のばらつきが $10 \%$ 程度で あることを確認した。材料＃10と\#11においてリー マー半径分 $(19 \mathrm{~mm})$ をストレートに押込み加工し、掘 削負荷（XYZ 方向合成值）と掘削時間を測定した。 ロボットによる臼蓋リーミングの検討するにあたり、 球形リーマーを一定の送り速度 $(300 \mathrm{~mm} / \mathrm{min})$ で材料
に押込み加工した場合と、外科医のリーミング時の 負荷力データを参考にセンサーで検出した負荷が最 大 $100 \mathrm{~N}$ となるように速度調節をした場合で、加工精 度や作業時間を計測した（条件は表 2 ）。また、掘削 実験材料の掘削形状を加工作業終了後に計測し、両 者の比較を行った。尚、外科医は外径 $38 \mathrm{~mm}$ の半球リ 一マーが実験材料ブロックに埋もれる位置を目視で 判断し、作業を終了したのに対し、ロボットでは、 内在計測系でリーマー半径の $19 \mathrm{~mm}$ 進めた位置で作 業を終了した。

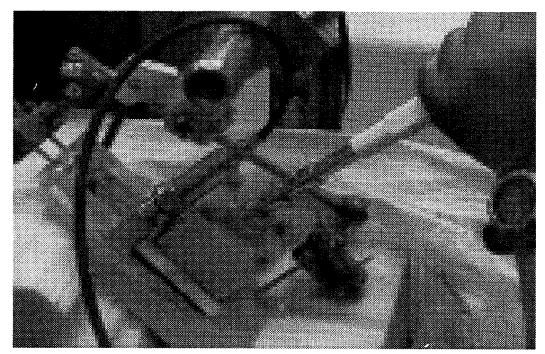

図 1 . 掘削負荷測定装置の外観

表 1. 臼蓋リーミング条件

\begin{tabular}{|c|c|}
\hline 手技器具 & $\begin{array}{l}\text { 球形 } リ-マ-\phi 38 \mathrm{~mm} \text { 、回転数 } \max 336 \mathrm{~min}^{-1} \\
\text { 新:新品、旧:使用済 (刃部磨耗量 } 0.19 \mathrm{~mm} \text { ) }\end{array}$ \\
\hline 人工骨材 & $\begin{array}{l}\text { Cellular Rigid Polyurethane Form } 4 \text { 種 } \\
\# 1522-09,10,11,12 \text { (密度: } 12>11>10>09 \text { ) }\end{array}$ \\
\hline カゼンー & IFS-67M25A25-I40 (Fx, Fy=100N, Fz=200N) \\
\hline 測定環境 & 空調:室温 $22^{\circ} \mathrm{C} 、$ 湿度 $60 \%$ \\
\hline
\end{tabular}


表 2.ロボットによる臼蓋リーミング条件

\begin{tabular}{|c|c|}
\hline 手技器具 & $\begin{array}{l}\text { 球形リーマー } \phi 38 \mathrm{~mm} \text { 、回転数 } \max 731 \mathrm{~min}^{-1} \\
\text { ・ロボット回転エットトルク不足のため回転数アップ } \\
\text { ・新、旧の工具は手技法と同一 }\end{array}$ \\
\hline 人工骨材 & $\begin{array}{l}\text { Ceiiular Rigid Polyurethane Form } 4 \text { 種 } \\
\text { ・\#1522-09〜12 は手技法と同一 } \\
\text { • 但し試験は } 2 \text { 回のみ実施 }\end{array}$ \\
\hline
\end{tabular}

【結果】外科医によるリーミング時の掘削負荷 (XYZ 方 向合成值）と掘削時間をを図 2 に示す。リーマーの切 れ味が悪い旧リーマーでは加工時間は長くなるが、 いずれも外科医の手の感覚により掘削負荷は最大 $100 \mathrm{~N}$ 程度で一定に保たれていることがわかる。

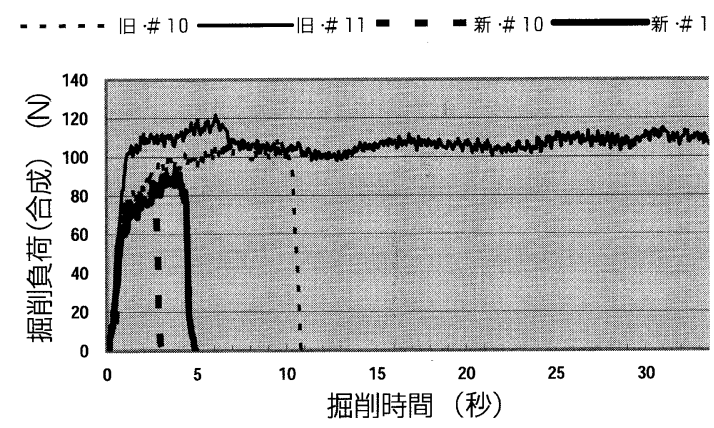

図 2.手技法による掘削負荷

一方、ロボットにより一定の送り速度で掘削した場 合、工具一回転当たりの掘削量は押込み位置が深く なるにつれて増大し、リーマー半径分押込んだ位置 で最大となった。掘削負荷はすぐに $100 \mathrm{~N}$ をオーバー した。

ロボットに最適送り速度制御の目標最大負荷を $100 \mathrm{~N}$ とし、送りスタート時の送り速度を $300 \mathrm{~mm} / \mathrm{min}$ とした場合、カセンサーの負荷監視による送り自動 加減速制御により、手技法と同様に掘削負荷を $100 \mathrm{~N}$ 程度に一定に保つことができた（図 3 )。

手技法による掘削とロボットによる掘削を比較す ると、同様の負荷状態でありながら旧工具の場合、 ロボットによる掘削時間が短いことがわかる。手技 法の場合、目視によりリーマー半径分 $(19 \mathrm{~mm})$ の押込 み量が誤差 $00.5 \mathrm{~mm}$ の範囲で加工されているのに対 し、ロボット加工では押込み量が 3〜 4mm 程度不足し ていた。これは、ロボットは予め指定した押込み量 $19 \mathrm{~mm}$ にて加工を終了するが、加工中のリーマーすな わちロボット回転ユニットと掘削負荷測定装置間の たわみによりワークが逃げて加工深さが不足したた めである。手技法の場合、測定装置のたわみ分を追 い込んで加工したため加工深さの不足量は小さくな ったが、反面加工時間が長くなった。
リーマーとワーク間の押込み加工方向の剛性は、 測定により $28 \mathrm{~N} / \mathrm{mm}$ すなわち $28 \mathrm{~N}$ の負荷で $1 \mathrm{~mm}$ のたわ み、100N では $3.6 \mathrm{~mm}$ のたわみになることが判った。 リーマー加工終了時の掘削負荷とそのワークの加工 深さ不足量の関係は、リーマーとワーク間の押込み 加工方向の剛性にほぼ一致していた（図 4)。

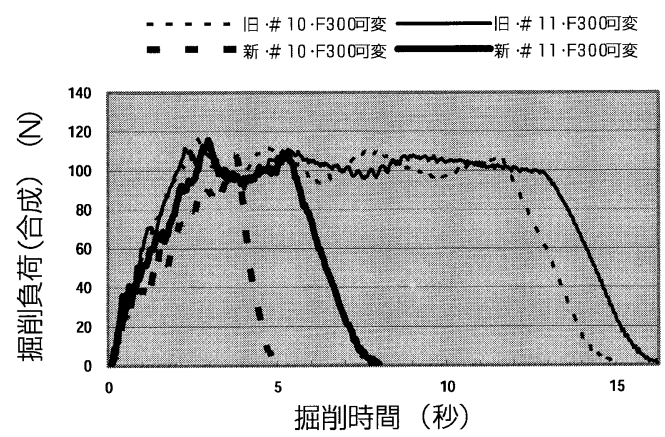

図 3.ロボットによる最適送り制御時の掘削負荷

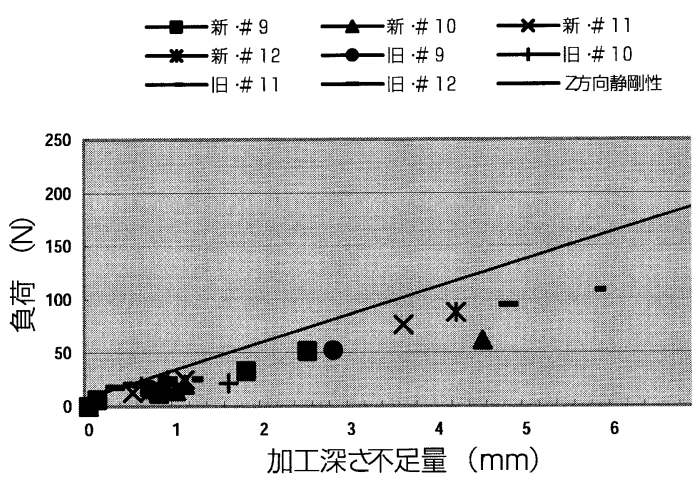

図 4. 掘削負荷と加工深さ不足量の関係

【考察】最適送り速度制御機能の付加により、手技 法の半球リーマーを用いて手技法と同様の掘削負荷 でロボットによる臼蓋リーミングの手術支援が可能 であることがわかった。ただし、半球リーマーと臼 蓋の剛性が小さいと加工深さが不足するため、リー マーと臼蓋の相対位置を監視し、押込み量の制御が 必要であることもわかった。本来、ロボットで臼蓋 リーミングの位置決めにはナビゲーションと連動さ せるため、赤外線での位置計測は可能である。しか しながら、剛性の問題からくる加工深さ不足につい て、100N に設定した最大負荷量を減らして送り速度 を遅くすることで解消できるかを負荷と速度データ

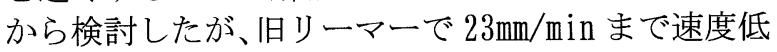
下して $100 \mathrm{~N}$ 以下となることから、スパイラル加工追 加などの掘削制御パスを追加するなどの工夫が必要 であると思われた。 
${ }^{a}$ 東京慈恵会医科大学高次元医用画像工学研究所, ${ }^{b}$ 東京慈恵会医科大学外科学講 座, ${ }^{\mathrm{c}}$ 東京慈恵会医科大学内視鏡科

Development of an image guided function for an endoscopic robot system

Asaki Hattori ${ }^{a}$, Naoki Suzuki ${ }^{a}$, Mitsuhiro Hayashibe ${ }^{a}$, Shigeyuki Suzuki ${ }^{a}$, Yoshito Otake ${ }^{a}$, Kazuki Sumiyama ${ }^{\mathrm{b}}$, Hisao Tajiric and Susumu Kobayashi ${ }^{\mathrm{b}}$

a Institute for High Dimensional Medical Imaging, The Jikei University School of Medicine, Tokyo, Japan

${ }^{\mathrm{b}}$ Department of Surgery, The Jikei University School of Medicine, Tokyo, Japan

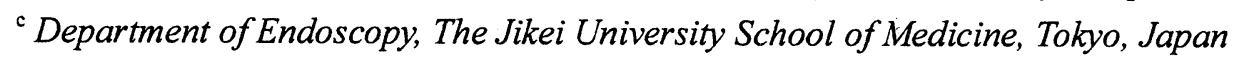

\begin{abstract}
We have developed an endoscopic robot system that enables various surgical procedures in the gastric tubes using two manipulators. During robotic surgery, surgeons often miss targeted 3D location or the direction of the endoscope's tip in an abdominal region. Therefore, we have developed an image guided function for the endoscopic robot system. This function uses two components: a magnetic 3D location sensor and a graphic work station. The magnetic 3D location sensor tracks the location and the direction of the tip of the endoscope. The graphic work station captures the endoscope's video image and superimposes the patient's organ models onto the image using measured values of the location sensor. In this paper, we will describe the system's overview and the result of an animal experiment that we performed using this system.
\end{abstract}

Keywords: image guided surgery, data fusion, endoscopic robot

\section{1.はじめに}

これまでにわれわれの研究グループでは、 左右に鉗子アームを持ち、より自由な外科的処 置が消化管内で可能な内視鏡ロボットの設計、 製作を行ってきた。本内視鏡ロボットによって、 高トルクを発生できる 2 本の腕を用いて目標の 軟組織をつかむ、持ち上げる等の開腹手術と同 様な操作をしながら手術作業が可能になった。 しかしながら通常の手術用ロボットでは、ロボ ットの視野が消化管内のどの位置で、どの方向 を向いているのかを把握することは難しく、こ れを認識するためには多くの経験を必要とする。 本研究では、これまでにわれわれが開発してき た Data Fusion システム ${ }^{1,2)}$ を内視鏡ロボットに 適用し、内視鏡ロボットの先端に磁気式の三次 元位置計測センサを設置して術中の先端位置を 計測し、術前に計測した CT データセットより 再構築した手術対象部位のオリエンテーション ならびに手術目標の三次元画像を術野画像に重 畳表示できる機能を持たせた。本報告では開発
システムをブタを用いた動物実験に適用した結 果について報告する。

\section{2. 方法}

本システムは、これまでに開発を行ってき た内視鏡ロボットと内視鏡ロボットの先端の三 次元位置を計測するための磁気式位置センサ

(mini BIRD, Ascension Technology Co.)、およ びあらかじめ再構筑した患者の臓器モデルを内 視鏡術野画像に重盢表示するための Graphic Workstation (GWS: OCTANE MXE, Silicon Graphics Inc.) により構成される。本システム の構成を Fig.1 に示す。位置センサは内視鏡口 ボット下部に固定し、ロボットの可動性を低下 させないように努めた（Fig.2）。本システムで は内視鏡の光学的なパラメ゙ータの計測の後、実 験動物の体表面上で再構築した体表面モデルと の registrationを行った。

重盢画像は術者の作業を妨げないように通 常の内視鏡画像とフットスイッチで術者が任意 に切り替えられるようにした。 


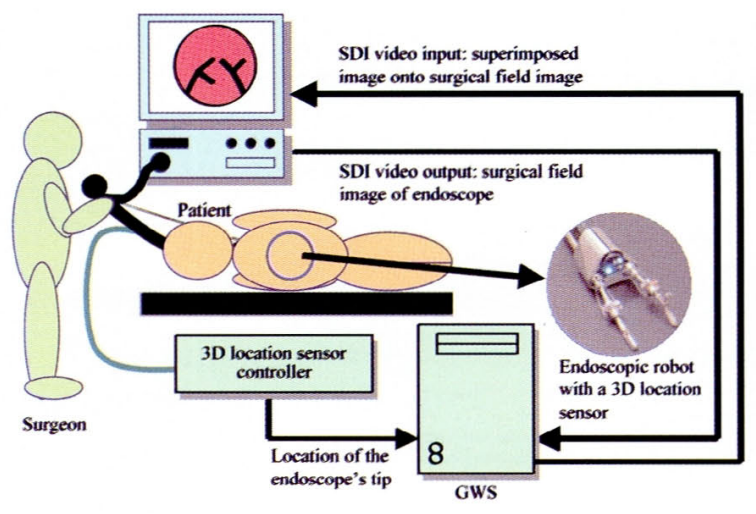

Fig. 1 System outline

\section{3. 結果}

本システムの機能をブタを用いた動物実験 に適用して検証を行った時の様子を Fig.3に示 す。本実験では、あらかじめ計測した X 線 CT データを用いて再構築した体表面、骨、肝臟、 肝内血管のモデルを用いた。Fig.4に内視鏡術 野画像に臓器モデルを重畳表示した時の様子を 示す。図は胃内部から肝臓側に内視鏡を向けた 時の様子を示しており、オリエンテーションを 得るための骨格像（春柱および肋骨）と手術目 標内構造物例である肝内血管が重盢されている。 図中の左上の小さなウィンドウは、方法の項で 述べた内視鏡先端と各臓器モデルとの位置関係 全体を任意の視点から確認できるウィンドウで ある。

\section{4. 考察}

ロボット内視鏡システムにおいて、内視鏡 の動きに追従してイメージガイド手術が可能な ナビゲーション機能の開発を行った。

今後は、システムの精度を向上させること で、より内視鏡ロボット手術に適したシステム の構築を行っていく予定である。

\section{参考文献}

1) 服部麻木，鈴木直樹，橋爪誠他. ナビゲーション 機能を備えたロボット手術システム（da Vinci） の開発. J JSCAS 2001; 3: 281-7.

2) Hattori A, Suzuki N, Hashizume $M$, et al. A robotic surgery system (da Vinci) with image-guided function. MMVR 2002: 188-94.

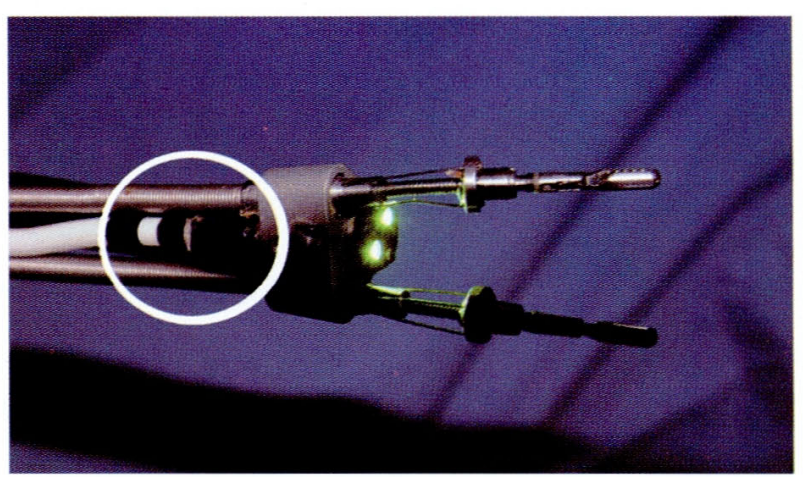

Fig. 2 An appearance of the endoscopic robot attached to a 3D location sensor

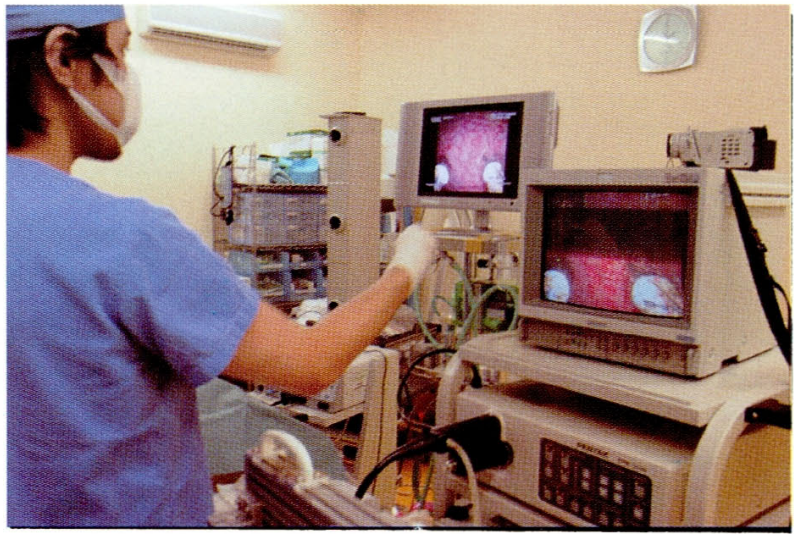

Fig. 3 A scene of an animal experiment (the left display is a normal endoscope view, the right display is a superimposed endoscope view that has an image guided function)

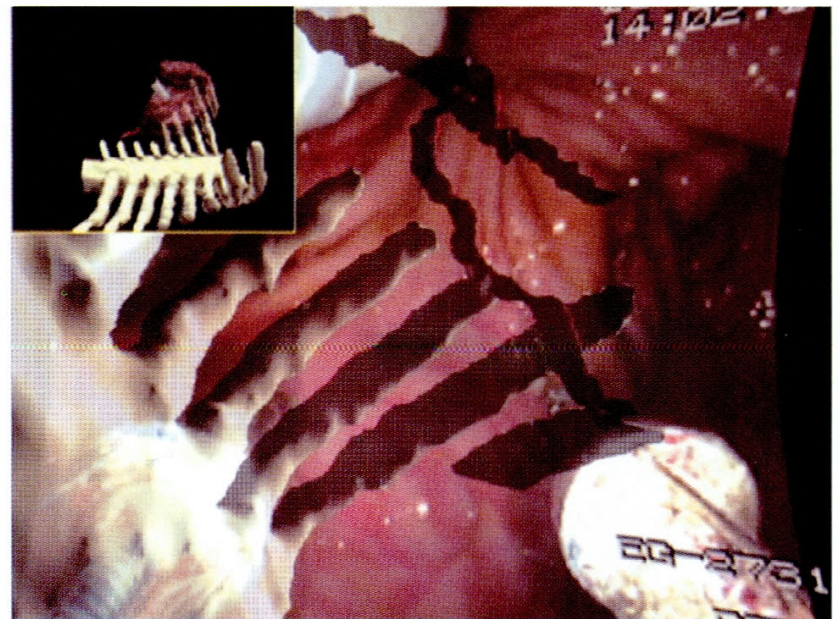

Fig. 4 A superimposed image on GWS display (organ models are superimposed onto the endoscope's image). Top left sub window shows a 3D location of an endoscope's tip in a surgical field. 